\title{
EXPERIMENTAL INVESTIGATION OF THE CRACK-INITIATION MOMENT OF CHARPY SPECIMENS UNDER IMPACT LOADING
}

\author{
EKSPERIMENTALNA PREISKAVA TRENUTKA INICIACIJE \\ RAZPOKE PRI UDARNI OBREMENITVI CHARPYJEVIH \\ VZORCEV
}

\author{
Valeriy Kharchenko, Evgeniy Kondryakov, Alexandr Panasenko \\ Institute for Problems of Strength, National Academy of Sciences, Tymiryazevska str. 2, Kyiv, Ukraine \\ alaenonn@ya.ru \\ Prejem rokopisa - received: 2014-07-09; sprejem za objavo - accepted for publication: 2014-09-05
}

doi:10.17222/mit.2014.103

\begin{abstract}
A new experimental method for the investigation of crack initiation and propagation was developed. Strain gauges on a specimen surface made it possible to obtain surface-deformation data. These data were compared with the force-time curve obtained using a vertical instrumented impact tester. An analysis of the results of this comparison enabled us to determine the moment of crack initiation on the force-time curve. Investigations of crack propagation were conducted in two orthogonal directions.

Keywords: Charpy specimens, crack, moment of crack initiation, specific zones of fracture
\end{abstract}

Razvita je bila nova eksperimentalna metoda za preiskavo iniciacije in rasti razpoke. Merilni lističi na površini vzorca omogočajo pridobivanje podatkov o deformaciji površine. Ti podatki so bili primerjani s krivuljo sila - čas, dobljeno iz instrumentirane vertikalne udarne naprave. Analiza rezultatov te primerjave omogoča določitev trenutka iniciacije razpoke na krivulji sila - čas. Preiskave rasti razpoke so bile izvršene v dveh ortogonalnih smereh.

Ključne besede: Charpyjevi vzorci, razpoka, trenutek iniciacije razpoke, posebna področja na prelomu

\section{INTRODUCTION}

At present, impact bending tests are one of the simplest and cheapest methods to determine the material properties that describe its tendency to brittle fracture. The simplicity and efficiency of this method, a relative ease of calibration and adjustment of the equipment allow this test method to be used in many areas of science and technology and industrial sectors, particularly, in the programs aimed to identify and predict the properties of reactor-vessel materials based on surveillance-specimen tests. ${ }^{1-3}$ Obtaining load diagrams for the contact between a specimen and a striker under impact loading with the use of strain gauges and modern recording systems implemented in a vertical instrumented drop-weight impact-testing machine, as well as a further comparison of the data-analysis results with the results of fractographic investigations, make it possible to get more important information about the crackpropagation mechanisms in Charpy specimens. ${ }^{4,5}$

\section{MATERIALS}

The present paper describes the results of an investigation of the moment of crack initiation and the features of crack propagation in Charpy V-notch specimens in the course of impact-bending testing on a vertical instrumented drop-weight impact-testing machine. The sche- me, the methods and the test procedures are described in detail. $^{6}$

Standard Charpy V-notch specimens were used. The specimen material is hot-rolled sheet of steel 45 , with a microstructure of a ferrite-pearlite mixture (Figure 1). The mean diameter of ferrite grains is $35 \mu \mathrm{m}$, and the mean diameter of pearlite grains is $54 \mu \mathrm{m}$.

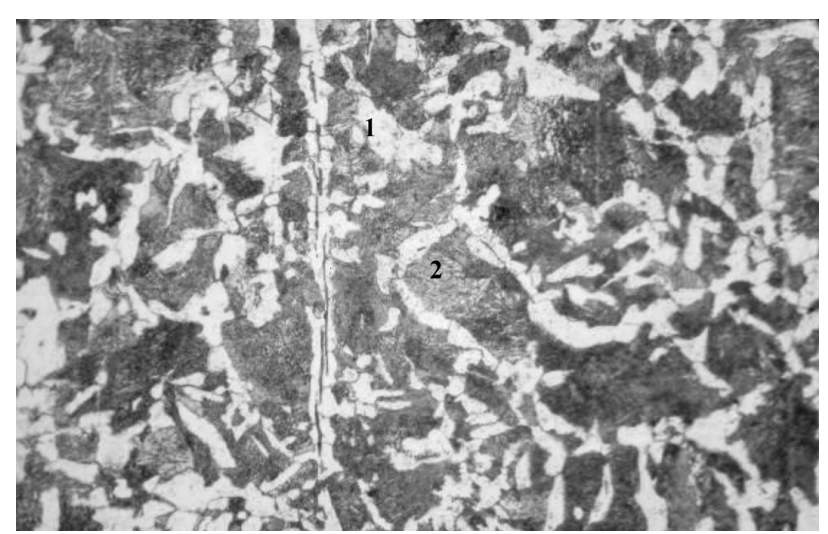

Figure 1: Microstructure of a specimen of steel 45, 500-times, 1 ferrite; 2 - pearlite

Slika 1: Mikrostruktura vzorca jekla 45, povečava 500-kratna, 1 ferit; 2 - perlit 


\section{METHODS AND EXPERIMENTAL WORK}

To investigate the moment of crack initiation and the features of its propagation, two directions of the crack propagation were chosen - the direction of the rolling plane and the one perpendicular to it.

Specimens were produced according to the State Standard of Ukraine GOST-9454-78. The dimensions of the specimens are $55 \mathrm{~cm} \times 10 \mathrm{~cm} \times 10 \mathrm{~cm}$. The notch parameters are: the notch depth $2 \mathrm{~mm}$, the convergence angle $45^{\circ}$, the curvature radius near the notch tip 0.25 $\mathrm{mm}$. The specimens were produced from a metal sheet with collinear directions of the principal axis of a specimen and the direction of the metal-sheet rolling plane. The plane of crack propagation was perpendicular to the direction of the rolling plane. Specimens with two different orientations of the crack-propagation direction were produced (Figure 2). The specimen marked with "T" has a notch orientation (and direction of crack propagation) perpendicular to the rolling plane. The specimen marked with "S" has a notch orientation (and direction of crack propagation) parallel to the rolling plane.

The crack propagation during the fracture of the Charpy specimens under impact bending has some specific features. ${ }^{7,8}$ With instrumented impact tests, diagrams of the impact contact force with the specimen force time $P(t)$ are obtained and their analysis enables us to describe every stage of the crack propagation in detail. A comparison of the diagram specific zones with the spe-

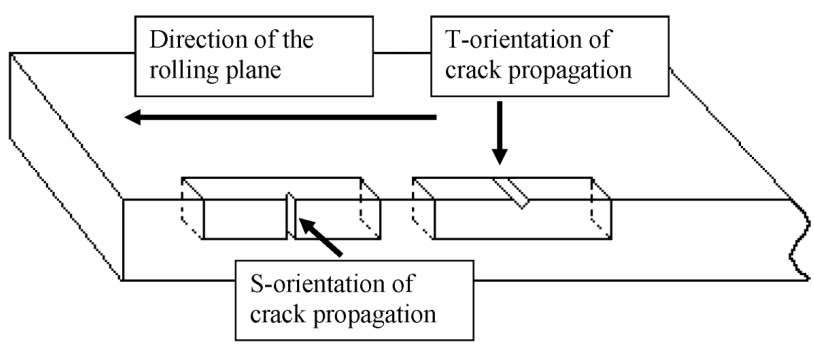

Figure 2: Scheme of the produced specimens with two different notch orientations (marked as $\mathrm{S}$ and $\mathrm{T}$ ) relative to the direction of the rolling plane

Slika 2: Shematski prikaz izdelave vzorcev z dvema orientacijama razpoke (oznaka $\mathrm{S}$ in $\mathrm{T}$ ) glede na smer ravnine valjanja

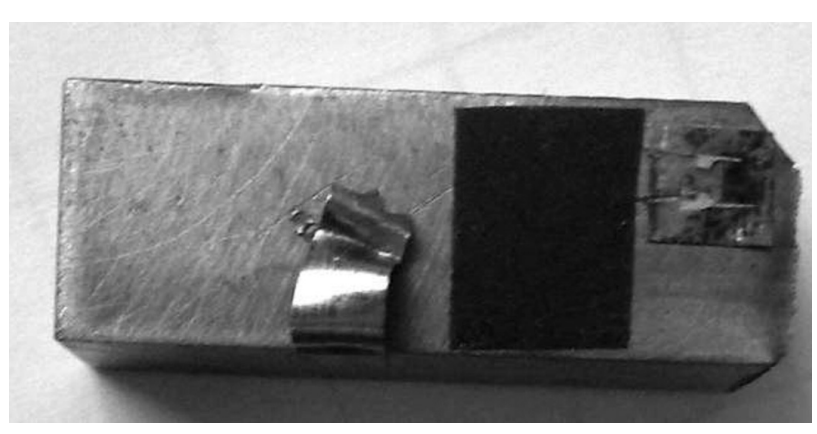

Figure 3: Half of the specimen with a strain gauge Slika 3: Polovica vzorca z merilnim lističem cific zones of the fracture makes it possible to calculate the specific energy for the crack propagation in a given zone and relate the energy to the fracture mechanism..$^{5,9}$

To determine the moment of crack initiation (brittle or ductile) in the $P(t)$ diagram, additional gauges for measuring lateral deformation were used. The gauges were located on the specimen surface near the V-notch concentrator along the assumed crack-propagation front (Figure 3). The signal recording the channels for the gauge and the $P(t)$ diagram were synchronized in time. The discretization of the signal in time was $2 \mathrm{e}-7 \mathrm{~s}$ (the sampling frequency was $5 \cdot 10^{6} \mathrm{~Hz}$ ). The temperature on the specimen surface during the testing was measured with a chromel/alumel thermocouple.

Fractographic investigations of the specimen fracture at the macro-level were performed using an AxiotechVario microscope, while the micro-zones of the specimen fracture were studied using a SEM-100U microscope.

\section{RESULTS AND DISCUSSION}

The height of the blade fall for the tested group varied from $0.05 \mathrm{~m}$ to $0.5 \mathrm{~m}$. A height $(h)$ of $0.1 \mathrm{~m}$ was used for a ductile/brittle crack initiation inside a specimen without an expansion on the lateral surface of the specimen. A height of $0.05 \mathrm{~m}$ was used for a shear-lip formation on the lateral surface without a crack initiation inside the specimen. A height of $0.5 \mathrm{~m}$ was used for the final rupture of the specimens with a brittle crack initiation followed by ductile crack growing.

All the experimental data with the parameters of the specimens and the test conditions are shown in Table $\mathbf{1 .}$

Figures 4 and 5 show the diagrams of the gauge signal and $P(t)$ and Figures $\mathbf{6}$ and $\mathbf{7}$ show the enlarged zones (in time) in the vicinity of the diagram maximum values for specimens $\operatorname{ShK} 7-1\left(T=25.8^{\circ} \mathrm{C}, h=1 \mathrm{~m}\right.$, the concentrator orientation is $\mathrm{S})$ and $\operatorname{ShK} 7-2\left(T=35{ }^{\circ} \mathrm{C}, h\right.$ $=1 \mathrm{~m}$, the concentrator orientation is $\mathrm{S}$ ). The maximum

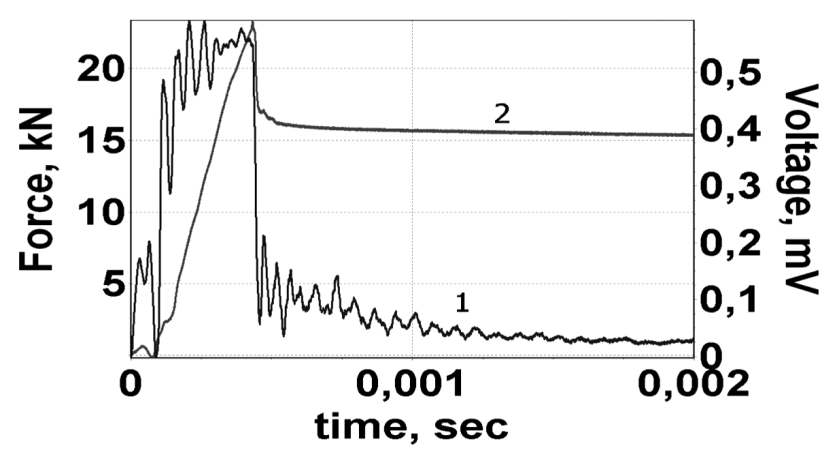

Figure 4: Specimen ShK7-1, $h=50 \mathrm{~cm}: 1$ - diagram of the striker contact with the specimen, 2 - diagram of the gauge signal

Slika 4: Vzorec ShK7-1, $h=50 \mathrm{~cm}$ : 1 - diagram stika kladiva $\mathrm{z}$ vzorcem, 2 - diagram signala iz merilnega lističa 
Table 1: Experimental data and test conditions

Tabela 1: Eksperimentalni podatki in razmere pri preizkušanju

\begin{tabular}{|c|c|c|c|c|l|}
\hline Specimen & $\begin{array}{c}\text { Notch } \\
\text { orientation }\end{array}$ & $\begin{array}{c}\text { Temperature, } \\
{ }^{\circ} \mathrm{C}\end{array}$ & $\begin{array}{c}\text { Height of the } \\
\text { blade fall, h/m }\end{array}$ & $\begin{array}{c}\text { Impact } \\
\text { velocity, } \mathrm{m} / \mathrm{s}\end{array}$ & \multicolumn{1}{|c|}{ Experimental result } \\
\hline ShK7-1 & $\mathrm{S}$ & 25.8 & 0.5 & 3.13 & Rupture with a brittle crack initiation \\
\hline ShK7-2 & $\mathrm{S}$ & 35 & 0.5 & 3.13 & Rupture with a brittle crack initiation \\
\hline ShK7-3 & $\mathrm{T}$ & 26.6 & 0.05 & 0.99 & No crack initiation, a shear-lip formation \\
\hline ShK7-3 & $\mathrm{T}$ & 26.6 & 0.1 & 1.4 & $\begin{array}{l}\text { Brittle-crack initiation in the center without } \\
\text { an expansion on the lateral surface of the } \\
\text { specimen }\end{array}$ \\
\hline ShK7-3 & $\mathrm{T}$ & 26.6 & 0.5 & 3.13 & Final rupture after an initiated brittle crack \\
\hline ShK7-4 & $\mathrm{T}$ & 23 & 0.1 & 1.4 & $\begin{array}{l}\text { Ductile-crack initiation and shear-lip } \\
\text { formation }\end{array}$ \\
\hline ShK7-4 & $\mathrm{T}$ & 23 & 0.5 & 3.13 & Final rupture after an initiated ductile crack \\
\hline
\end{tabular}

force is situated close to the beginning of drastic force reduction.

The diagrams for specimen ShK7-2 have similar shapes (Figure 5). The results of the specimen testing at various temperatures revealed that the maximum value of the gauge diagram has a tendency to shift mainly to the left, with an increase in the temperature, in the direction of the maximum value of the $P(t)$ diagram.

The fractographic analysis revealed several typical zones on the fracture surfaces: a stable crack-growth area, an unstable crack-jump area, a rupture area and a shear-lip area. Figure 8 presents a macro-fracture of specimen ShK7-1. An analysis of the physical interpretation of the strain-gauge diagram suggests that the essential feature of the fracture of these specimens is the form of a stable crack-growth area, which is of an elongated triangle or trapezoid with the maximum length (in the direction of the main crack propagation) in the central section of the specimen and with the minimum length (frequently close to zero) at the fracture edges, i.e., close to the lateral surfaces of the specimen (the shear-lip zone).

Thus, a crack initiation is most likely to occur in the middle of a specimen with the subsequent extension to the surface, which relates to the formation of lateral necking (shear lips).

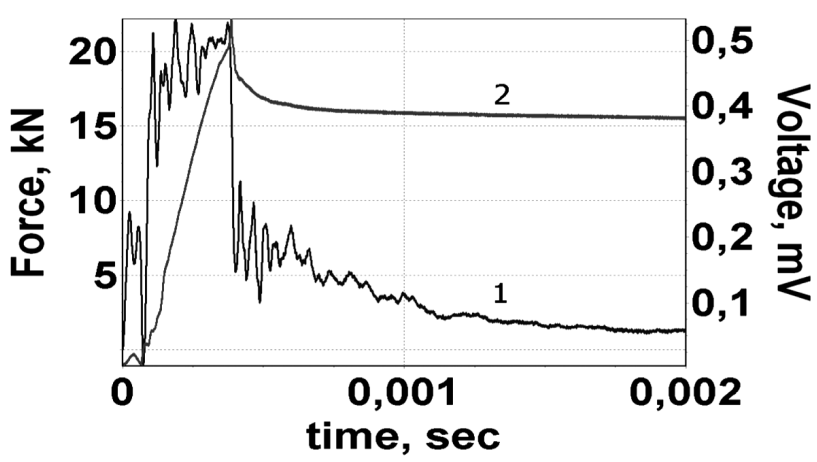

Figure 5: Specimen ShK7-2, $h=50 \mathrm{~cm}$ : 1 - diagram of the striker contact with the specimen, 2 - diagram of the gauge signal Slika 5: Vzorec ShK7-2, $h=50 \mathrm{~cm}$ : 1 - diagram stika kladiva $\mathrm{Z}$ vzorcem, 2 - diagram signala iz merilnega lističa
To confirm the given assumption, additional strain tests on the Charpy specimens with and without a crack initiation were conducted. In the light of this fact it is obvious that the strain gauge responds to the strain of a specimen surface during the brittle-crack propagation (an unstable crack-jump area). It is improbable that the gauge will register an initiation of a crack of a stable growth considering its current shape and dimensions.

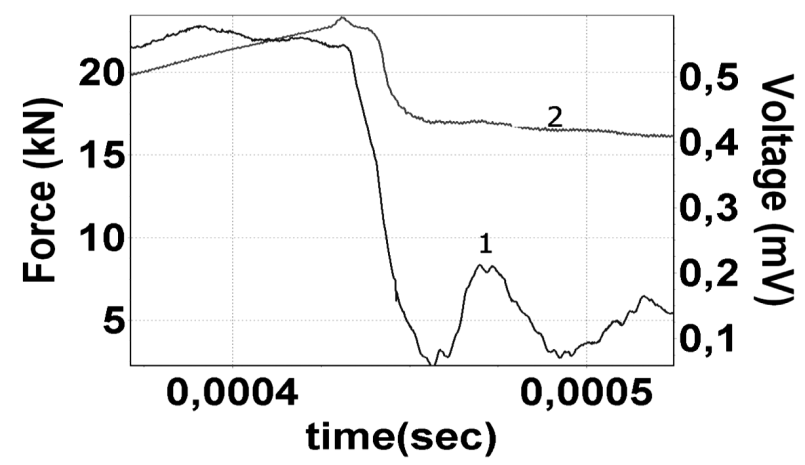

Figure 6: Specimen $\mathrm{ShK} 7-1, h=50 \mathrm{~cm}$. An enlarged section: 1 diagram of the striker contact with the specimen, 2 - diagram of the gauge signal.

Slika 6: Vzorec ShK7-1, $h=50 \mathrm{~cm}$. Povečano področje: 1 - diagram stika kladiva z vzorcem, 2 - diagram signala iz merilnega lističa.

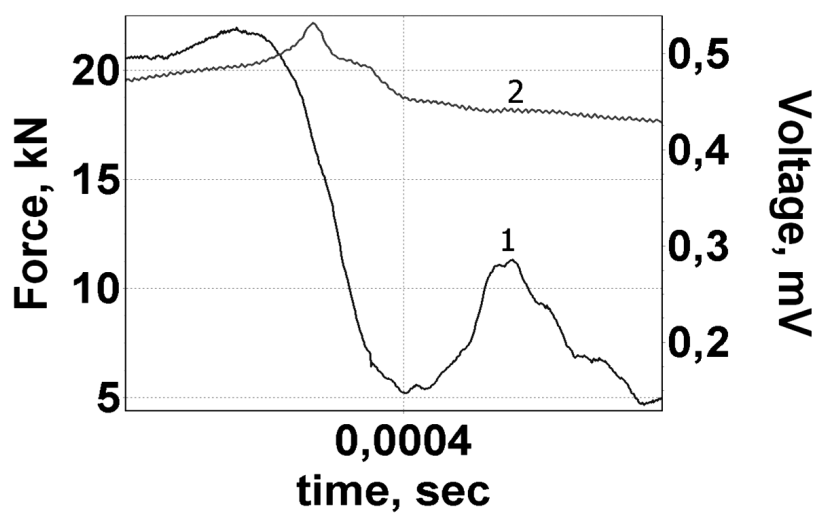

Figure 7: Specimen ShK7-2, $h=50 \mathrm{~cm}$. An enlarged section of the diagrams: 1 - diagram of the striker contact with the specimen, 2 diagram of the gauge signal.

Slika 7: Vzorec ShK7-2, $h=50 \mathrm{~cm}$. Povečano področje: 1 - diagram stika kladiva z vzorcem, 2 - diagram signala iz merilnega lističa. 


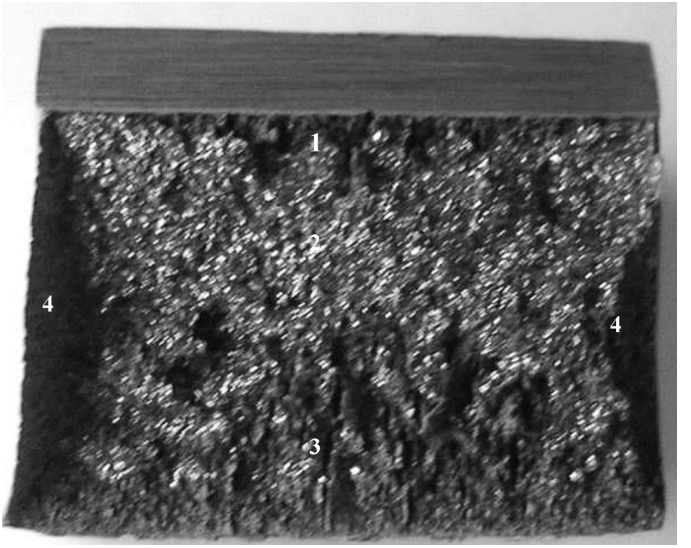

Figure 8: Fractograph of a macro-fracture of a Charpy specimen: 1 stable crack-growth area, 2 - unstable crack-jump area, 3 - rupture area, 4 - shear lips

Slika 8: Makroposnetek preloma Charpy vzorca: 1 - področje stabilne rasti razpoke, 2 - nestabilno področje skoka razpoke, 3 - prelom pri upogibu, 4 - strižne ustnice

Using these considerations one can explain the fact that the maximum value in the gauge diagram does not coincide with the maximum value in the contact diagram, as it is shifted to the right in time with respect to the contact diagram.

The values for the striker velocity at the moment of its contact with a specimen, at which the specimen underwent deformation without a crack initiation, were determined by varying the values of the height $(h)$ of the blade fall.

Figure 9 shows the diagrams of the strain gauge and $P(t)$ for specimen ShK7-3 $\left(T=26.6{ }^{\circ} \mathrm{C}\right.$, the concentrator orientation is T) at the impact velocity of $1 \mathrm{~m} / \mathrm{s}$. At this impact velocity no crack initiation is observed (during a visual inspection using optical methods both on the surfaces and inside the concentrator). Moreover, the gauge registered the strain on the specimen surface (a shear-lip initiation).

It should be mentioned that the maximum value of the gauge signal was significantly lower $(0.32 \mathrm{mV})$ com-

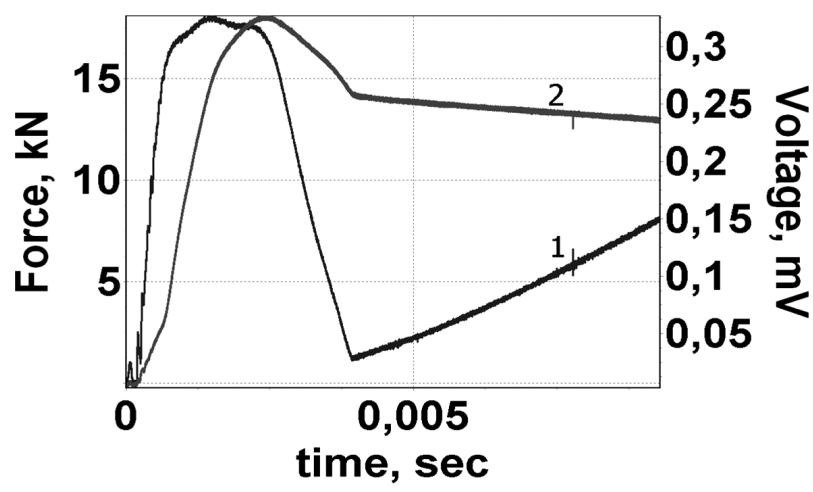

Figure 9: Specimen $\mathrm{ShK} 7-3, h=5 \mathrm{~cm}: 1$ - diagram of the striker contact with the specimen, 2 - diagram of the gauge signal

Slika 9: Vzorec ShK7-3, $h=5 \mathrm{~cm}$ : 1 - diagram stika kladiva z vzorcem, 2 - diagram signala iz merilnega lističa

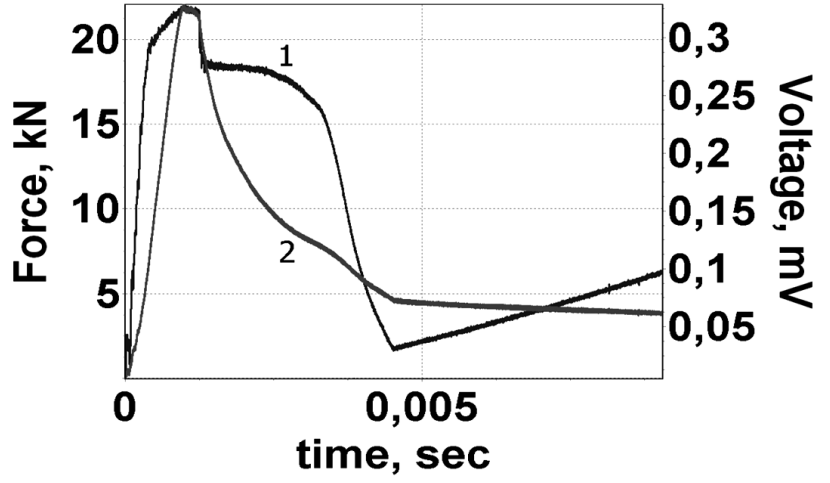

Figure 10: Specimen ShK7-3, $h=10 \mathrm{~cm}: 1$ - diagram of the striker contact with the specimen, 2 - diagram of the gauge signal

Slika 10: Vzorec ShK7-3, $h=10 \mathrm{~cm}: 1$ - diagram stika kladiva $\mathrm{z}$ vzorcem, 2 - diagram signala iz merilnega lističa

pared with the maximum value of the gauge signal at the crack initiation $(0.55 \mathrm{mV})$.

At the impact velocity of $1.4 \mathrm{~m} / \mathrm{s}$ (Figures $\mathbf{1 0}$ and 11) a crack initiated in the central section of specimen ShK7-3 (Figure 12). It is obvious that the crack nucleates in the central section of the specimen (the

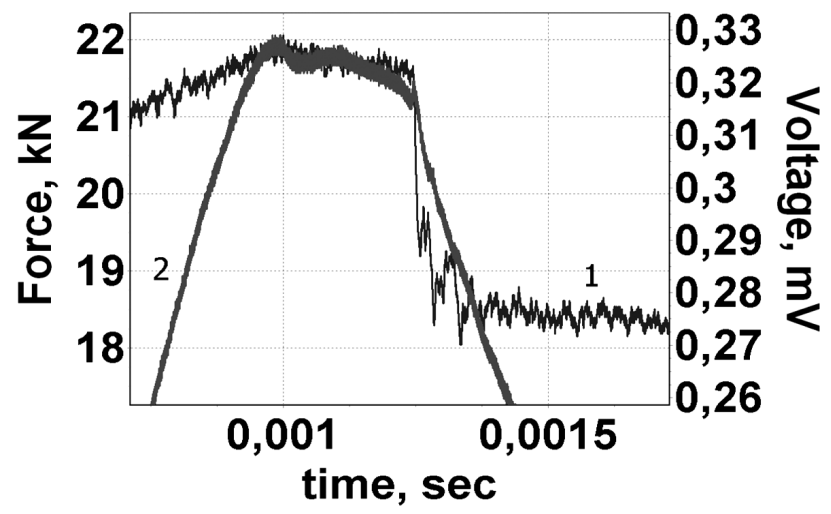

Figure 11: Specimen ShK7-3, $h=10 \mathrm{~cm}$. An enlarged section of the diagrams: 1 - diagram of the striker contact with the specimen, 2 diagram of the gauge signal.

Slika 11: Vzorec ShK7-3, $h=10 \mathrm{~cm}$. Povečano področje: 1 - diagram stika kladiva $\mathrm{z}$ vzorcem, 2 - diagram signala iz merilnega lističa.

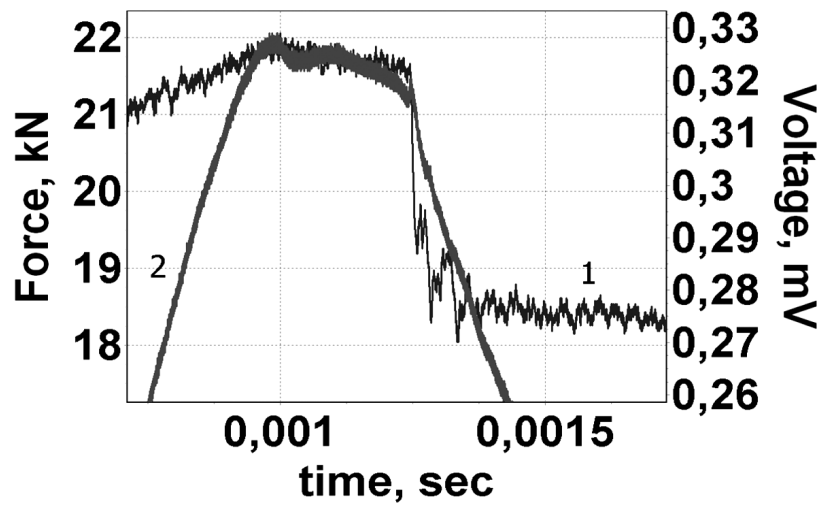

Figure 12: Specimen ShK7-3 (initiated crack), $h=10 \mathrm{~cm}$ Slika 12: Vzorec ShK7-3 (začetna razpoka), $h=10 \mathrm{~cm}$ 


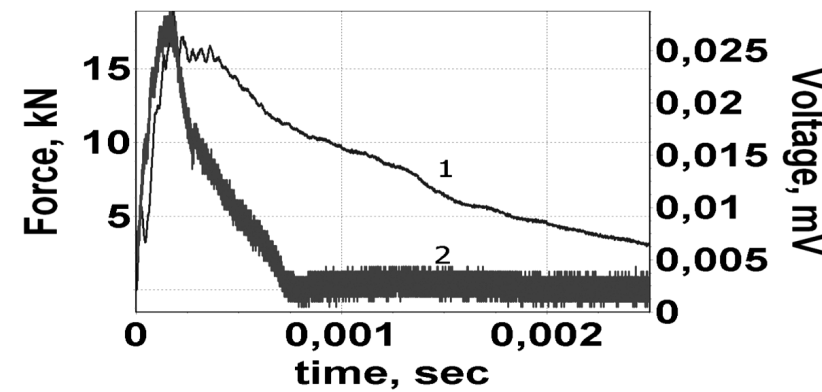

Figure 13: Specimen ShK7-3, $h=50 \mathrm{~cm}: 1$ - diagram of the striker contact with the specimen, 2 - diagram of the gauge signal

Slika 13: Vzorec ShK7-3, $h=50 \mathrm{~cm}: 1$ - diagram stika kladiva $\mathrm{Z}$ vzorcem, 2 - diagram signala iz merilnega lističa

crack opening has the maximum value - of approximately $1 \mathrm{~mm}$ in the center).

In specimens ShK7-3 and ShK7-4, at the impact velocity of $1.4 \mathrm{~m} / \mathrm{s}$, the initiated cracks did not extend to the lateral surfaces of the specimens (Figure 12). The $P(t)$ diagram clearly shows the region of an abrupt decrease in the force at the moment of brittle-crack initiation and propagation in the central section of the specimen.

Then, the specimen was fractured at the impact velocity of $3 \mathrm{~m} / \mathrm{s}$. Figure 13 provides a diagram of the fracture. Like in the $P(t)$ diagram there is a lack of the area of deformation/crack initiation; the initial section has the form of a straight line (elastic deformation) with its fluctuations. This is related to the presence of the crack initiated in specimen ShK7-3.

A large area of a stable crack growth and an area of an unstable crack jump (brittle fracture) formed at the impact velocity of $1.4 \mathrm{~m} / \mathrm{s}$ are shown on Figure 14 .

Figure 15 shows the diagram of the gauge signal and the $P(t)$ diagram for specimen ShK7-4. The crack initiation was similar to the one in specimen ShK7-3 after the impact with the velocity of $1.4 \mathrm{~m} / \mathrm{s}$. The crack

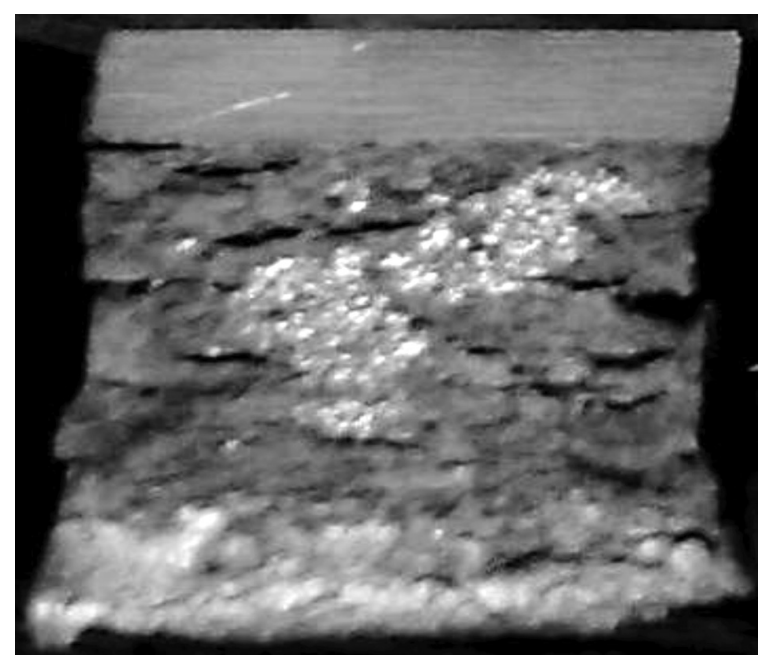

Figure 14: Specimen ShK7-3 (fracture)

Slika 14: Vzorec ShK7-3 (prelom)

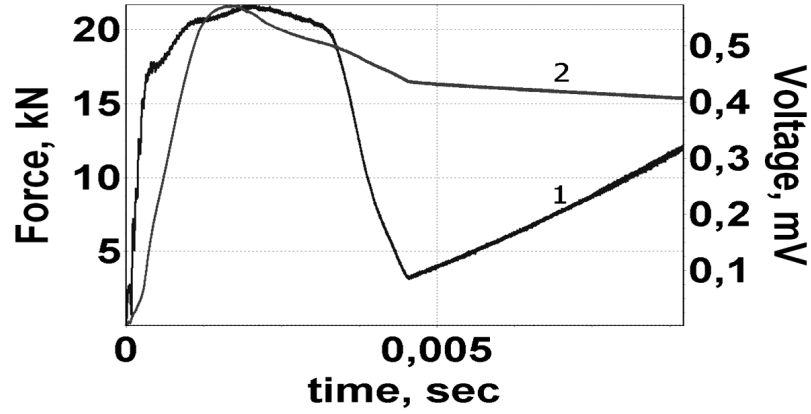

Figure 15: Specimen ShK7-4, $h=10 \mathrm{~cm}$ : 1 - diagram of the striker contact with the specimen, 2 - diagram of the gauge signal

Slika 15: Vzorec ShK7-4, $h=10 \mathrm{~cm}: 1$ - diagram stika kladiva $\mathrm{z}$ vzorcem, 2 - diagram signala iz merilnega lističa

initiated inside the specimen and it demonstrated its maximum opening in the specimen central section, but did not extend to the lateral surfaces of the specimen (Figure 16). The gauge-signal diagram has its maximum value shifted to the left, relative to the maximum value in the $P(t)$ diagram.

In this case the gauge measuring the strain on the specimen surface did not register the initiation of a stable

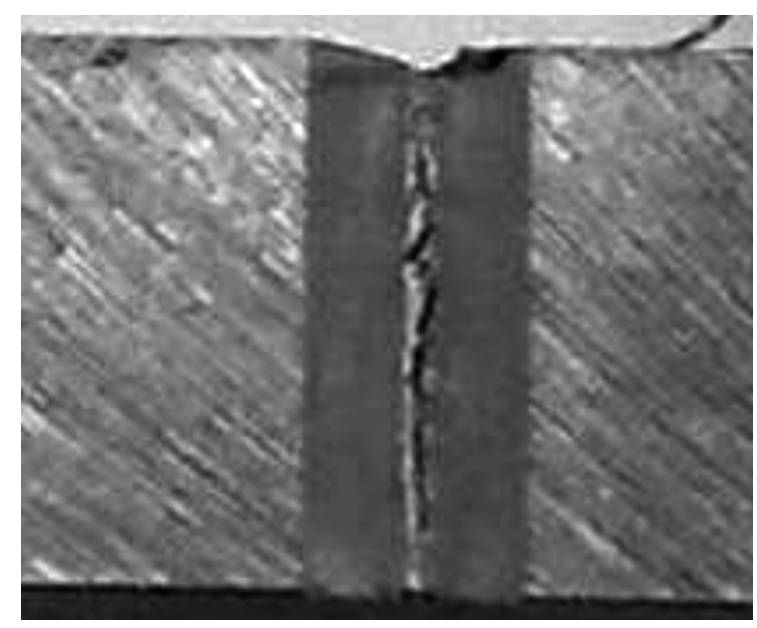

Figure 16: Crack nucleation, specimen ShK7-4, $h=10 \mathrm{~cm}$ Slika 16: Nukleacija razpoke, vzorec ShK7-4, $h=10 \mathrm{~cm}$

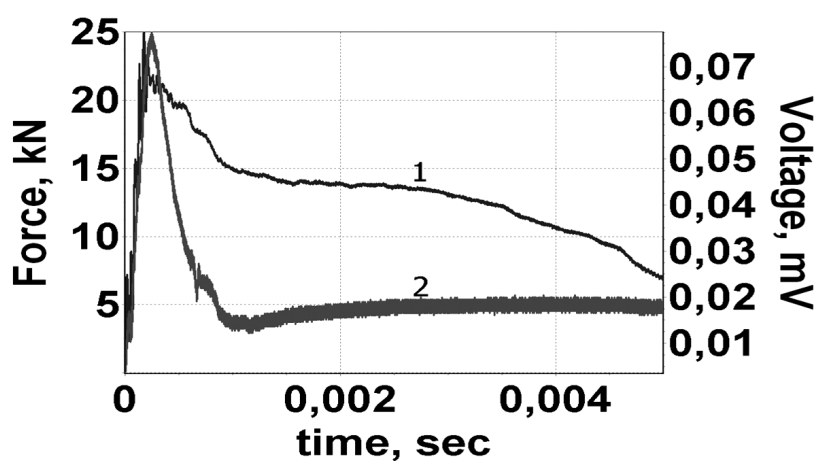

Figure 17: Specimen ShK7-4, $h=50 \mathrm{~cm}$ : 1 - diagram of the striker contact with the specimen, 2 - diagram of the gauge signal

Slika 17: Vzorec ShK7-4, $h=50 \mathrm{~cm}$ : 1 - diagram stika kladiva $\mathrm{z}$ vzorcem, 2 - diagram signala iz merilnega lističa 


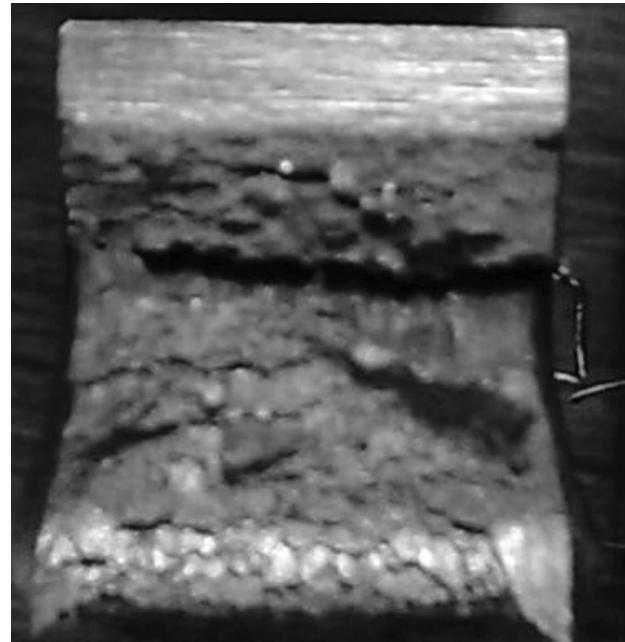

Figure 18: Fracture of specimen $\mathrm{ShK} 7-4$

Slika 18: Prelom vzorca ShK7-4

ductile crack inside the specimen. The crack did not extend to the specimen lateral surfaces.

The $P(t)$ diagram does not include the area of an abrupt force decrease, which implies the propagation of an unstable brittle crack in the specimen.

Specimen ShK7-4 was fractured at the impact velocity of $3 \mathrm{~m} / \mathrm{cm}$. The $P(t)$ diagram for specimen ShK7-4 (Figure 17) is similar to the diagram for specimen ShK7-3 (Figure 13).

The deformation/crack initiation site is not observed and the force increases linearly with the time in the initial part of the diagram. The maximum value in the gauge-signal diagram is more to the left compared with the one for specimen ShK7-3. The signal level is very low $(0.028 \mathrm{mV})$, which evidences a significant deformation of the gauge tracks after the impact with the velocity of $1.4 \mathrm{~m} / \mathrm{s}$. At the fracture there is no unstable (brittle) crack-jump site (Figure 18); however, the gauge registered the moment of a ductile crack extension to the specimen lateral surface as demonstrated by its diagram.

The conducted investigations showed that the used procedure for the determination of the crack-initiation moment exhibits a number of drawbacks associated primarily with the formation of lateral necking. To obtain more accurate results, specimens with deep side grooves should be used to eliminate the influence of the specimen lateral-surface deformation.

\section{CONCLUSIONS}

The investigations of the moment of crack initiation in Charpy V-notch specimens were performed. The procedure of recording the crack initiation during the impact-bending testing using a vertical instrumented impact tester was developed and tested. A comparison of the gauge diagrams with the striker-contact diagrams made it possible to determine the moment of crack initiation in the contact diagram. The comparison of the gauge/deformation diagrams with the results of the fractographic investigations enabled us to find the relation between the moment of crack initiation in the striker contact diagram and the specimen with specific fracture zones.

It was determined that a crack in a Charpy specimen formed during the impact-bending testing is initiated in the specimen central section. The applicability of the given procedure for recording both a brittle-crack initiation in the specimen central section and a propagation of a ductile crack to the specimen lateral surface was shown.

There are large differences between the material properties of the specimens with the T-orientation and S-orientation. This difference can be revealed during an impact-loading test. The shapes of the diagrams of the specimens with different orientations of the notch are significantly different.

\section{REFERENCES}

${ }^{1}$ PNAE-G-007-86 Norms based on the strength of equipment and pipelines of nuclear power plants, Energoatomizdat, Moscow 1989

${ }^{2}$ VERLIFE - Unified Procedure for Lifetime Assessment of Components and Piping in WWER NPPs, European Commission under the Euratom Research and Training Programme on Nuclear Energy, Version 8, 2008, $275 \mathrm{p}$

${ }^{3}$ RD EO 1.1.2.09.0789-2009 - Method of determining fracture toughness according to test results witness samples underlying strength and life of WWER - 1000 NPPs, Energoatomizdat, Moscow 2009

${ }^{4}$ Standard ISO EN DIN 14556 Instrumented Impact Test, Deuth Verlag, Berlin 2000

${ }^{5}$ R. Chaouadi, A. Fabry, On the utilization of the instrumented Charpy impact test for characterization the flow and fracture behavior of reactor vessel steels, European Structural Integrity Society, 30 (2002), 103-117, doi:10.1016/S1566-1369(02)80011-5

${ }^{6}$ V. Kharchenko, E. Kondryakov, V. Babutskii, V. Zhmaka, An instrumented testing machine for impact tests: basic elements, operation analysis, Reliability and Life of Machines and Structures, 27 (2006), $121-130$

${ }^{7}$ V. Kharchenko, E. Kondryakov, A. Panasenko, Crack propagation peculiarities in steels at Charpy and disc-shaped specimens tests, Questions of nuclear science and technology, 84 (2013) 2, 31-38

${ }^{8}$ L. Botvina, Fracture, Kinetics, Mechanisms, General Laws, Nauka, Moscow 2008 (in Russian)

${ }^{9}$ V. Goritskii, Thermal embrittleness of steel, Metalurizdat., Moscow 2007 